DOI: 10.17234/SRAZ.65.44

UDK: 811.134.2'373.49

UDK: 811.163.2'373.49

Original scientific paper

Recibido el 28 de abril de 2020

Aceptado para la publicación el 25 de noviembre de 2020

\title{
La vejez, las enfermedades y la muerte reflejadas en los eufemismos y disfemismos fraseológicos
}

\author{
Véselka Nénkova \\ Universidad de Plovdiv "Paisiy Hilendarski" \\ veselka@gmail.com
}

El objetivo del presente trabajo consiste en reflexionar sobre el uso de las unidades fraseológicas eufemísticas y disfemísticas que los hablantes hispanohablantes y búlgaros utilizan tanto en los textos escritos, como en las conversaciones cotidianas para referirse a la vejez, a ciertas enfermedades y a la muerte. A partir de varios ejemplos, extraídos de obras lexicográficas, literarias y la prensa contemporánea, presentaremos un análisis de los fraseologismos eufemísticos y disfemísticos relacionados con los temas en cuestión.

Palabras clave: eufemismo, disfemismo, fraseologismos, metáfora, creatividad

En los tiempos antiguos el uso de expresiones eufemísticas se vinculaba al tabú lingüístico, mientras que hoy en día su uso se relaciona más bien con el lenguaje políticamente correcto. Como señala Montero Cartelle (2000: 550), “ya no se teme la palabra, sino las asociaciones y las connotaciones que despierta".

En la actualidad las causas que inducen al eufemismo son de orden afectivo, asociativo y social. Las expresiones eufemísticas -aunque en un principio es posible que algunas de ellas hayan surgido como consecuencia del tabú- ahora se utilizan para evitar lo molesto, lo grosero, lo obsceno, lo despectivo y lo ofensivo.

El objetivo de nuestro trabajo es presentar una visión general sobre el tema y analizar cómo se conceptualiza metafóricamente la vejez, las enfermedades y la muerte en las expresiones fraseológicas eufemísticas y disfemísticas españolas y búlgaras, ya que, como es sabido, el acervo fraseológico de un determinado pueblo es una fuente valiosa de las creencias y costumbres paganas, religiosas y culturales que han influido en la formación de la percepción del mundo por parte de los hablantes.

Si partimos de la definición que da el diccionario de la RAE (2019), un eufemismo es una "manifestación suave o decorosa de ideas cuya recta y franca expresión sería dura o malsonante", fácilmente comprenderemos la finalidad de la imposición hoy en día del uso del lenguaje políticamente correcto en las instituciones y en los medios de comunicación. Lo políticamente correcto exige 
que se proceda a la sustitución de una palabra o una expresión no grata por otra más agradable y menos chocante.

En todas las fuentes revisadas el eufemismo se analiza como oposición al disfemismo y estos dos sustantivos se proponen como antónimos. El DRAE (2019) nos ofrece la definición canónica del disfemismo como "modo de decir que consiste en nombrar una realidad con una expresión peyorativa o con intención de rebajarla de categoría, en oposición a eufemismo".

Para Casas Gómez el disfemismo, como el eufemismo, se basa "en un principio de sustitución, mas a diferencia de su antónimo, [...] busca, con los mismos recursos lingüísticos, no ya la mitigación o atenuación, sino su efecto contravalente, la motivación o reforzamiento del signo interdicto" (1986: 85-86).

Veamos los siguientes ejemplos extraídos de obras literarias:

(1) A los pocos compases le hizo acordarse de su madre, que estaba en el otro mundo, y de su novia, que le había dado calabazas. (Clarín 2001: 66)

(2) [...] el distraído y erudito Fernando Vidal, pasaba a mejor vida por la vía sumaria de los clásicos y muy conservadores cuatro tiros. (Clarín 2001: 112)

(3) Los míos ya están en el Cielo, así que no les puedo preguntar. (Casariego 2009: 219)

(4) Y luego agarré la jarra del agua y la estrellé sobre ella, con tan buena fortuna que estiró la pata sin decir ay, o lo que diablos digan las ratas cuando les dan lo suyo. (Pérez-Reverte 2005: 210)

(5) Y, ¿cómo le vas a pagar el billete si las dobla? (Delibes 1989: 126)

En los cinco ejemplos los autores se refieren a la muerte a través de varios fraseologismos. En los tres primeros casos se están utilizado con clara intención afectiva los eufemismos estar en el otro mundo, pasar a mejor vida y estar en el cielo, y en los ejemplos (4) y (5) los autores echan mano de los disfemismos estirar la pata y doblarlas para dar un toque coloquial al discurso.

Como rasgo general, los investigadores (entre otros, Lázaro Carreter 1968; Porzig 1974; Casas Gómez 1986; González de Gambier 2002; Estébanez Calderón 2004; Vucheva 2008; Kojouharova 2013) coinciden en que el disfemismo posee connotaciones peyorativas y aclaran que los disfemismos se emplean cuando se quiere menospreciar el valor de un objeto o de una persona.

Eftimova (Ефтимова 2016: 131) apunta que en la actualidad, con la finalidad de no dañar la imagen de las personas que padecen ciertas discapacidades, se llega a denominaciones, a veces incluso cómicas, por ejemplo, xора cbc cлyхови затруднения (personas con dificultades auditivas) en vez de глухи хора (personas sordas), хора със зрителни затруднения (personas con dificultades visuales) en vez de слепи хора (personas ciegas), хора в неравностойно положение (gente en posición desfavorecida) en vez de инвалиди (inválidos), хора с ментални или психически затруднения (personas con dificultades mentales o psíquicas) en vez de ^уди хора (personas locas), пацчиенти с алкохолна зависилост (personas con 
dependencia alcohólica) en vez de alcohólicos, деца със спецุиални образователни потребности (niños con necesidades educativas especiales) en vez de niños autistas, disléxicos, etc. Adecuadas o no, estas expresiones rápidamente se lexicalizaron o están en vía de lexicalización, ya que el lenguaje políticamente correcto de las instituciones públicas las impuso.

Reflexionando sobre ciertas acuñaciones metafóricas recientes que utilizan los políticos y los economistas, Álex Grijelmo (2007: 188-189) habla de metáforas mentirosas. En la esfera social nos inclinamos más bien por llamarlas piadosas, ya que, pensemos, por ejemplo, si no es una verdadera demostración de piedad cuando nos referirnos a una persona postrada en cama como a "una persona con movilidad reducida", "se encuentra en una cama" y "es usuario de una silla de ruedas" ${ }^{\prime \prime}$, si bien es evidente que esta persona carece por completo de la posibilidad de moverse, es decir, se trata de una inmovilidad permanente. Estas expresiones suenan bastante curiosas, si no inapropiadas, y no raras veces dan pie a la creación de juegos lingüísticos de doble sentido como en una canción búlgara -interpretada por los rock cantantes Georgi Minchev y Milena Slavovaen la cual se juega con la expresión estar en cama. En dicha canción el protagonista cuenta que está entrando en una farmacia y puesto que hay mucha cola pide permiso con la excusa de que "a mí me está esperando una persona en cama". Acto seguido el protagonista aclara que lo que quiere comprar es un preservativo y así se gana la indignación y la rabia de los clientes. El protagonista no se sirve de mentiras para que le cedan el paso, ya que evidentemente una persona puede encontrarse en una cama no solo por imposibilidad de moverse, sino también por placer, de donde surge lo cómico en la situación y la frase estar en cama tiñe de humorismo la canción.

Montero Cartelle (1981: 87-88) subraya que el contexto determina si una palabra o una expresión adquiere la capacidad eufemística o disfemística, no solo el contenido semántico de estas, y Chamizo Domínguez (2004: 45) añade que “El que una palabra dada (o una expresión, en su caso) sea sentida por los hablantes como un eufemismo o como un disfemismo no depende de la palabra en sí, sino del contexto, del uso que se haya hecho de dicha palabra o de las intenciones de los hablantes". Un eufemismo puede sonar incluso como afrenta. Veamos el siguiente ejemplo:

Desde la rebelión militar no había tenido un día de reposo.

- Ya descansarás cuando estés muerto.

Rió un poco el Almirante, oscuro y como para sí mismo, de su propia broma. Y es que a menudo, pensó Falcó, el humor de su jefe rondaba lo siniestro; [...] Así tu viuda sabrá por fin dónde duermes, era capaz de decir, y otras bromas semejantes, que maldita la gracia tenían. (Pérez-Reverte 2016: 15)

La réplica "Ya descansarás cuando estés muerto" -que hace alusión a la metáfora conceptual MORIR ES DESCANSAR y que está reflejada en la expresión

1 http://www.webmati.es/index.php?option=com_content\&view=article\&id=46:termi nos-adecuados-para-referirnos-a-personas-con-discapacidad\&catid=14\&Itemid=163 (11.10.2019) 
eufemística descansar en paz-adopta un tono peyorativo con respecto al concepto que designa, de esa manera, y mediante la adición mordaz "Así tu viuda sabrá por fin dónde duermes", el interlocutor consigue molestar e incluso ofender al receptor. Como vemos, en determinados contextos los eufemismos se pueden utilizar incluso como disfemismos con la finalidad de desacreditar a una persona, de demostrar ironía, sarcasmo o desprecio.

En los medios de comunicación se utilizan numerosos recursos eufemísticos lexicalizados o en vía de lexicalización para hablar del envejecimiento y la vejez. En español y en búlgaro respectivamente se prefieren usar sustantivos acompañados de adjetivos para no mencionar directamente la vejez: personas mayores/възрастни хора; personas de edad avanzada/хора в напреднала възраст; personas de tercera edad/хора в трета възраст; población mayor/възрастно население, etc. Son sumamente peyorativas las expresiones ser un carca y ser un carroza referido a una persona vieja.

En el pasado las enfermedades se sustituían por eufemismos debido a las creencias de que las palabras poseen una fuerza mágica. Para no provocar la aparición de la enfermedad se disimulaba su propio nombre. Se creía que las enfermedades son seres vivos o demonios a los que no les gusta oír sus nombres (Попов 2000). Así la sífilis fue denominada la enfermedad francesa o el mal francés, y la epilepsia el gran mal o la gota coral.

En la actualidad los medios de comunicación, por regla general, tratan de atenerse a las normas de lo políticamente correcto. En la prensa amarilla, sin embargo, la ética no se respeta tanto y en sus páginas las enfermedades se mencionan directamente o incluso se sustituyen por disfemismos que suenan humillantes e hirientes.

Llamar a la enfermedad por su propio nombre puede causar molestias en la conversación entre médico y paciente, por eso no raras veces se recurre a expresiones eufemísticas que suavicen la información que se transmite al paciente. Así, como señala Mitkova (2014: 163), por delicadeza o por temor se utilizan eufemísticos como mal de pulmón o T.B.C. en vez de 'tuberculosis', una larga enfermedad en vez de 'cáncer' o estar mal de cabeza en vez de 'estar loco', etc. También se recurre a sustituciones de dependencias como, por ejemplo, usuario de sustancias adictivas o personas con dependencia narcótica por 'drogadicto' y personas con dependencia alcohólica por 'alcohólico'. Con varias expresiones disfemísticas se llaman a las personas con dificultades visuales y auditivas: duro de oídos; ser un cuatro ojos, no ver dos/tres en un burro; corto de vista, etc.

La muerte desde tiempos inmemoriales es entendida por la gente como parte inseparable de la vida. En la cultura occidental la muerte es el acontecimiento más aterrorizador de la existencia humana y supone el inevitable final de la vida terrenal. El miedo a la muerte y el deseo de que exista otra vida después de la muerte han dado pie a la aparición de numerosas expresiones fraseológicas. Petkova (Петкова 2017: 31) distingue entre eufemismos éticos y eufemismos manipulativos y explica que los relacionados con la muerte forman parte de los eufemismos éticos que se basan en el tabú.

Chamizo Domínguez observa que si, según la opinión común, la metáfora consiste en dar a una cosa el nombre que pertenece a otra, "entonces eufemismos 
y disfemismos podrían ser considerados como metáforas, o al menos como un caso especial de metáfora" (2004: 45).

La formulación de los modelos metafóricos y las archimetáforas nos ofrecen una amplia base a través de la cual podemos conocer los mecanismos de conceptualización que utiliza el ser humano para denominar a la vejez, las enfermedades y la muerte. Así, por ejemplo, algunas de las metáforas conceptuales más difundidas en relación con la muerte son: LA MUERTE ES VIAJAR: emprender el último viaje/búlg. отивах си от този свяm; MORIR ES SUBIR AL CIELO: irse al cielo/búlg. отивам на небето; MORIR ES ACABÁRSELE A UNO EL TIEMPO EN LA TIERRA: llegarle a alg. la hora/búlg. изпял съм си песента; MORIR ES DEJAR DE SUFRIR: ya no sufrir más/búlg. nреставам да страдам; MORIR ES ABANDONAR: dejar este mundo/búlg. напускам този свяm; MORIR ES DORMIR Y DESCANSAR: descansar en paz/búlg. заспивам вечен сън, еtс.

Basándose en los esquemas presentados, se puede concluir que ambas lenguas, objeto de nuestro estudio, explotan recursos afines basados en metáforas conceptuales que ofrecen expresiones paralelas de coincidencia absoluta o parcial. Las diferencias que se dan entre las realizaciones metafóricas entre una lengua y otra se deben, de acuerdo con Kiuchukova-Petrinska (2019: 257), sobre todo, a diferencias culturales, ideológicas y mitológicas.

\section{Conclusiones}

El presente trabajo recoge las variadas formas en que los hablantes españoles y búlgaros expresan sus sentimientos ante la vejez, la enfermedad y la muerte a través de fraseologismos eufemísticos y disfemísticos. Ambas lenguas explotan recursos afines basados en metáforas que a menudo ofrecen expresiones paralelas de coincidencia absoluta. En los equivalentes parciales subyacen idénticas metáforas conceptuales que sirven como muestra de que ciertas expresiones han partido de similares caminos de motivación.

Por medio de eufemismos y disfemismos se designa el objeto denotado de manera indirecta. Los eufemismos tratan de minimizar el impacto de las asociaciones que provocan las palabras vejez, enfermedad y muerte. Los disfemismos, por otra parte, son expresiones cargadas de ironía a través de las cuales se trata de sustituir los nombres de ciertas enfermedades, la vejez y la muerte.

La vitalidad del eufemismo en la actualidad es incuestionable, sin embargo, ya no vive solo a causa del tabú que lo ideó, sino al deseo de suavizar la información y a la necesidad de hacer el discurso socialmente correcto. 


\section{Bibliografía}

Casas Gómez, Miguel (1986). La interdicción lingüística. Mecanismos del eufemismo y del disfemismo, Cádiz: Publicaciones de la Universidad de Cádiz.

Chamizo Domínguez, Pedro José (2004). La función social y cognitiva del eufemismo y del disfemismo, en: Panace@, vol. V, № 15, marzo, 2004, pp. 45-51.

Ефтимова, Андреана (2016). Евфемизми и дисфемизми за болести в медиите, в: Българистични четения, Szeged: JATEPress, стр. 127-135.

Kiuchukova-Petrinska, Boriana (2019). Conceptualización metafórica del miedo en la fraseología española y búlgara“, en: La lengua y la literatura: encuentros, desafíos, influencias. 55 años de filología hispánica en la Universidad de Sofía San Clemente de Ohrid [eds. Tatiana Panteva et al.], Sofia: Editorial Universitaria "San Clemente de Ohrid", pp. 251-258.

Kojouharova, Stefka (2013). Tropos y figuras literarias en el discurso periodístico español (Observaciones sobre los artículos de economía en el periódiсо El País), еn: Научни трудове, Филология, т. 51, кн. 1, СБ. А, Пловдив: Университетско издателство „Паисий Хилендарски“, рр. 388-398.

Mitkova, Adriana (2014). Acercamiento pragmático y sociolingüístico al discurso eufemístico, en: Мислене, език, реч. Изследвания в чест на проф. дфн Евгения Вучева. Pensamiento, lengua, habla. Estudios en honor de la catedrática Eugenia Vucheva [ed. Nikola Krastev], Sofia: Editorial Universitaria "San Clemente de Ohrid", pp. 162-169.

Montero Cartelle, Emilio (2000). El tabú, el eufemismo y las hablas jergales, en: Introducción a la Lingüística española [dir. Manuel Alvar], Barcelona: Ariel, pp. 547-563.

Петкова, Силвия (2017). Эвфемизация как явление непрямой коммуникации, в: Научни трудове, том 55, кн. 1, СБ. Б, Пловдив: Университетско издателство „Паисий Хилендарски“, стр. 30-40.

Попов, Борислав (2000). Табуистични названия на болести в югозападните български говори, в: Македонски преглед, 1, 65-80.

Porzig, Walter (1974). El mundo maravilloso del lenguaje. Problemas, métodos y resultados de la lingüística moderna, Madrid: Gredos.

Vucheva, Evgenia (2008). Estilística del español actual. Teoría y práctica del estilo, Sofía: Editorial Universitaria "San Clemente de Ojrid".

\section{Fuentes}

Casariego, Martín (2009). La jauría y la niebla, Sevilla: Algaida.

Clarín, Leopoldo Alas (2001). Las dos cajas / Двете кутии, двуезично издание, София: НОМАД.

Delibes, Miguel (1989). El disputado voto del señor Cayo, Barcelona: Áncora y Delfín.

Estébanez Calderón, Demetrio (2004). Diccionario de términos literarios, Madrid: Alianza.

González de Gambier, Emma (2002). Diccionario de terminología literaria, Madrid: Síntesis. 
Grijelmo, Álex (2007). La seducción de las palabras, Madrid: Punto de lectura. Lázaro Carreter, Fernando (1968). Diccionario de términos filológicos, Madrid: Gredos.

Pérez-Reverte, Arturo (2005). Limpieza de sangre, Madrid: Santillana Ediciones Generales, S. L.

Pérez-Reverte, Arturo (2016). Falcó, Madrid: Alfaguara.

Real Academia Española (2019). Diccionario de la Real Academia Española, <https:// dle.rae.es/diccionario> (29.09.2019).

\section{Old age, disease and death reflected in the phraseological euphemisms and dysphemisms}

The main purpose of this report is to consider the use of euphemistic and dysphemistic phraseological units used by Spanish speaking people and Bulgarians in both written and spoken language to name old age, illness and death. Through various examples drawn from lexicographic and literary works, as well as from the contemporary press, we offer an analysis of the euphemistic and dysphemistic phraseological units related to the topics covered in the report.

Key words: euphemism, dysphemism, phraseology, metaphor, creativity 
